\title{
The Rice Processing Industry in Nepal: Constraints and Opportunities
}

\author{
Krishna Dev Joshi1 ${ }^{\circledR}$, Santosh Upadhyay1, Pashupati Chaudhary², Suchit Shrestha3, \\ Kamal Bhattarai ${ }^{4,5}$, Bhaba Prasad Tripathi ${ }^{1}$
}

\author{
${ }^{1}$ International Rice Research Institute, Nepal Office, Vegetable Crops Development Centre, Lalitpur, Nepal \\ ${ }^{2}$ Agriculture and Forestry University, Rampur, Chitwan, Nepal \\ ${ }^{3}$ Karma Group of Companies, Kathmandu, Nepal \\ ${ }^{4}$ International Rice Research Institute (IRRI), Strategic Innovation Platform, Metro Manila, Philippines \\ ${ }^{5}$ Institute of Crop Science (ICropS), College of Agriculture and Food Science, University of the Philippines Los Baños (UPLB), \\ Los Baños, Philippines \\ Email: k.d.joshi@irri.org
}

How to cite this paper: Joshi, K.D., Upadhyay, S., Chaudhary, P., Shrestha, S., Bhattarai, K. and Tripathi, B.P. (2020) The Rice Processing Industry in Nepal: Constraints and Opportunities. Agricultural Sciences, 11, 1060-1080.

https://doi.org/10.4236/as.2020.1111069

Received: September 25, 2020

Accepted: November 15, 2020

Published: November 18, 2020

Copyright ( 2020 by author(s) and Scientific Research Publishing Inc. This work is licensed under the Creative Commons Attribution International License (CC BY 4.0).

http://creativecommons.org/licenses/by/4.0/ (c) (i) Open Access

\begin{abstract}
A rice mill survey covering diverse rice processing companies in terms of their milling output, type of technology and year of establishment was conducted to understand the current situation of the rice milling industry and to identify enablers and barriers to its growth in Nepal. Coarse rice varieties dominate Nepal's rice processing industry, with a $42 \%$ share by total weight, followed by medium rice (34\%) and fine varieties (less than 7\%). Polished white rice (Arwa) was the dominant rice type in Nepal in the survey, followed by parboiled and steamed rice. The price and profit margins increased from coarse to fine rice varieties and from Arwa to parboiled and steamed rice. The cost of milling also followed a similar trend. The rice milling industry in Nepal largely influences the adoption or non-adoption of any specific type of rice variety by dictating specific brands in the market and this has important implications for rice research and development. The rice processing industry of Nepal was unable to compete with the Indian rice milling industry because of: 1) low profit margins due to the high cost of rice production and procurement, 2) a lack of economies of scale, 3) a lack of milling technologies for long and extra-long and steamed rice in the country and a lack of investment to modernize rice milling technology, and 4) unavailability of paddy throughout the year locally. Millers were willing to upgrade their rice milling technology to include high throughput parboiling, steamed rice as well as long and extra-long grain rice. This will be a strategic decision in counteracting the ever-increasing rice imports in Nepal. We believe that the findings of the study will be vital for formulating an appropriate rice research, development and rice processing strategy for Nepal to achieve food and nutritional security and the Sustainable Development Goals.
\end{abstract}




\section{Keywords}

Rice Industry, Grain Quality, Economy of Scale, Rice Varieties, Rice Imports, Value Chain, Processing Technology, Efficiency, Profit Margins, New Strategy, Nepal

\section{Background}

\subsection{Importance of Rice in Nepal}

Rice is Nepal's most important staple food crop and an important source of income for the farmers. About $73 \%$ of rice is produced in the Terai, $24 \%$ in the hills, and $4 \%$ in the high hills [1]. Rice is critical to food and nutrition security (67\% of total cereal consumption and $23 \%$ of protein intake), employment, and income for farmers in addition to its contribution to the economy; e.g. $20 \%$ to Agricultural Gross Domestic Product and 7\% to GDP [2] [3]. Time-series data show that rice production grew at the rate of $1.8 \%$ per annum from 1961-63 to 2010-12 which was below the population growth rate of $2.3 \%$ per annum [1].

With improved road infrastructure, urbanization and higher income, more people in the hilly and mountainous regions of Nepal are also switching to rice-based diets and demand for all categories of rice, including branded fine, aromatic, and long grain rice, is increasing [4]. However, the country's rice production is shortfall of about one million tons of milled rice, spurring increasing rice imports [1]. Current rice production and productivity need to be substantially increased to meet the increasing demand for rice.

However, Nepal lacks the technical capacity and appropriate milling technologies and has a weak private sector; therefore, the country needs support to meet these challenges. Nepal imports rice worth more than USD 300 million each year, mainly from India [5]. As a major drain on the national budget, this also has adversely affected development as this money could be used to address food and nutrition security, and reduce rural poverty, and delivery of the Sustainable Development Goals (SDGs).

\subsection{The Rice Value Chain in Nepal}

Agriculture is the second-largest sector of the economy, contributing $27 \%$ of the GDP in 2019 , and $57 \%$ of the working age population are employed in the sector [6]. However, farmers largely practice subsistence farming, with half of the workforce employed in the sector producing only for their own consumption with nearly $40 \%$ selling only in case of surpluses and only $10 \%$ cultivating for commercial purposes [7]. The rice value chain (VC) in Nepal is largely characterized by an informal and less developed market system. Vertical and horizontal linkages among the key rice VC actors are almost missing because of the lack of trust and poor functional relationship among market actors [8]. Nearly $88 \%$ of farmers sell their paddy from their homestead without any value addition [9]. 
Lack of functional relationships has resulted in weak vertical and horizontal linkages among key value chain actors. The rice milling technology currently employed in Nepal is not suitable for fine long and extra-long rice varieties, but it could be upgraded with some investment.

Large-scale collectors, large millers, and wholesalers dominate the rice supply chain. Demand for rice is increasing every year, so domestic production can neither meet local demand nor compete with cheaper rice from India. Unusual price fluctuations because of imports of cheaper and poor-quality rice from India are almost common features of the rice industry in Nepal, with serious implications [3]. Rice imported from India is cheaper for several reasons: 1) the lower cost of production in India (because of the government subsidy for inputs for rice production, processing, and milling), 2) rice produced in Nepal is not considered to be of international standard, and 3) market distortion through malpractice of repackaging and attractive branding of poor-quality rice from India mixed with some good-quality product.

In the rice value chain (VC) farmers do not usually calculate the cost of production while their analysis is that the productivity and profitability of rice are low due to the inadequate use of modern technologies and practices and the high cost of production (inputs and labor) [8] [9] [10]. The major transactions of paddy between farmers and collectors take place from November to January, while medium and large-scale collectors may store paddy for 6 to 9 months to obtain a higher market price when rice is in short supply in the market. Rice VC activities include carrying paddy from fields after harvesting, threshing, cleaning, bagging, storing, transporting to the market, and selling to traders or to millers, and then the millers convert the paddy into rice by de-husking, polishing, grading, packaging, and distributing it. Rice millers are the key actors in milling, grading, packaging, distributing to different markets, and selling to the ultimate consumers [11].

Nepal's rice producers are mainly subsistence and semi-subsistence in nature. Most farmers sell paddy immediately after harvest to fulfil their cash requirements. But profit margins vary in the rice value chain because of market imperfections, unequal bargaining power among different actors, and unavailability of market information in a timely manner [8] [9]. If the VC actors know the benefit of participating in an improved value chain, this will ensure optimum quality of paddy and rice, which in turn will also increase the ultimate consumer's welfare. Milling, upgrading, and value-chain development have significant implications for food security, poverty alleviation, and overall economic development.

\subsection{The Rice Milling Industry in Nepal}

The rice milling industry has a vital role in the overall rice value chain for product differentiation and value addition to paddy after the milling process to produce intended products such as brown rice, polished rice, parboiled rice, and steamed rice. An efficient rice milling machine should ensure consistency in the quality of the end product and hence enhance the economic value of the raw material. Han- 
dling large volumes of rice consistently with the least recurring costs by conserving energy and properly using human resources are the desirable features of a modern rice mill. A modern rice processing machine, vis-à-vis an outdated one, produces consistent-quality products with as much as $3 \%-5 \%$ less breakage of rice grains, a net power saving of $15 \%-20 \%$, and practically negligible downtime [12].

Rice millers in Nepal perform three major functions in the value chain: 1) purchasing paddy, 2) milling paddy, and 3) selling rice and by-products. The performance and efficiency of rice mills in terms of head rice recovery, milling percentage, and quality of milled rice depend on many things: quality of paddy, appropriate milling technology to match with the grain type of rice, efficiency, and high throughput of machines.

We believe that this study is first of its kind in Nepal. No literature or empirical studies appear to be available about rice milling technology and the current state of the industry in terms of various constraints and opportunities in Nepal. Moreover, research on the rice milling industry, rice product differentiation, product development, and branding in Nepal is also limited. A study of the rice milling industry would provide the overall context within which to examine the drivers and barriers to growth of the rice sector ultimately to contribute to rice self-sufficiency in Nepal. The rice milling industry ultimately dictates the type of rice varieties that can be grown and processed in a country and therefore this matter is of vital importance in formulating a rice research strategy for Nepal to achieve food and nutritional security and the Sustainable Development Goals.

\section{Objectives of the Study}

The main objective of the study is to identify the enablers and barriers to growth of rice processing industry in Nepal.

Another objective of the study was to become familiar with and analyse the rice milling industry as to how it influences specific rice varieties that can or cannot be commercialized in Nepal that are key to achieving food and nutritional security and contribute to the sustainable development goals (SDGs) in Nepal.

\section{Methods}

A study was done by the International Rice Research Institute (IRRI) to understand the current situation and emerging trends of the rice processing industry in Nepal. Secondary information were collected and analysed to identify the major locations where rice mills are operating. Focus group discussions (FGDs) were done and identified 3 Terai clusters namely Eastern, Central and Western. From those clusters, 16 market centres beside east-west highway and its link road to Southern border were identified for rice mills survey. Key Informants Interview (KII) was done with District level members of chamber of commerce and trade, district mill association, rice wholesalers and traders to get an idea on linkage of rice millers with traders, price flow and market share. The questionnaire was pre-tested and based on the responses it was refined for making it 
more informative and respondent friendly. The information from KII were triangulated with the information given by respondents. Similarly observed and interacted with operators or staffs of the rice mills, wholesale market and supermarkets to get information on their capacity, current status and market share. All, these data were documented.

At each market centre, three mills were surveyed including at least one large and one medium sized mills. Fifty rice milling companies covering small, medium, and large mills were studied from March to April 2018 with the purpose of understanding the annual turnover capacity, milling technology, grain type of rice milled, and other features of the rice mills. Direct observations and face-to-face interviews using semi structured and structured questionnaires were done with mill owners or managers in their rice mills to collect data. The information from the KIIs was triangulated with the information given by respondents, e.g. owner, or operators or staff of the rice mills, wholesale market, and supermarkets to obtain information on their capacity, current status, and market share. Case studies of selected rice mills were documented to understand the dynamics of rice imports into Nepal and their implications for the rice milling industry.

The mills were categorized into small, medium, and large types on the basis of hourly rice processing capacity. Rice mills with turnover of 3 tons or more per hour were categorised as large rice mills, 1 to 3 tonnes as medium, and less than 1 tonne per hour capacity as small rice mills.

Secondary information on the rice milling industry of Nepal was collected from various sources and analysed prior to the field study to identify the locations with major concentrations of rice mills in the Terai region. The Terai was classified into three regions: the Eastern cluster covering the locations from Jhapa in the east to east of the Bagmati River, Nawalpur of Sarlahi District; the Central cluster between west of the Bagmati River and Daunne hill of Nawalpur District; and the Western cluster covering the locations from Sunwal of Nawalparasi District to Mahendranagar of Kanchanpur District. From those clusters, 16 market centers along the East-West highway and its link roads leading to the Southern market places close to the Indian border were identified for the survey. At each market center, three mills were surveyed covering one each of large-, medium-, and small-sized mills (Figure 1).

After collecting the information, the completed questionnaires were reviewed and then the data were coded, validated and analysed.

\section{Results}

\subsection{Rice Mills in the Surveyed Area}

A total of 50 rice mills were surveyed, of which 12 were large, 21 medium, and 17 small. The majority of medium and large mills were associated with the areas having higher rice production and productivity, whereas the small mills were concentrated in those districts where either the area under rice is low or productivity is lower (Figure 1). The age of the surveyed rice mills ranged from 2 to 48 


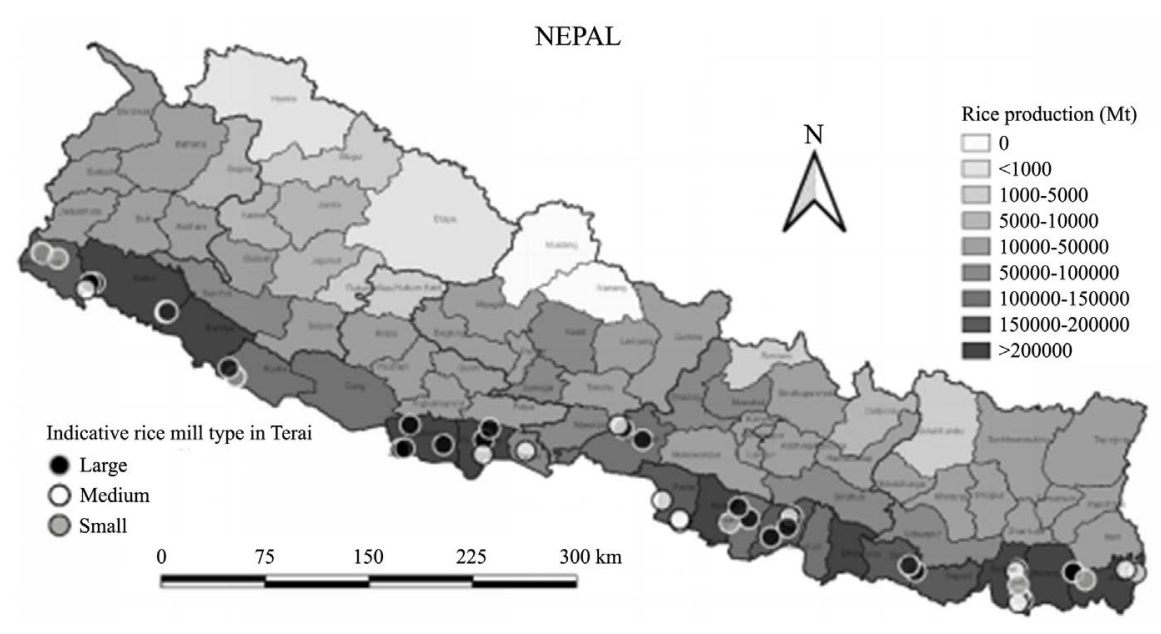

Figure 1. Location of surveyed rice mills and major rice production districts of the Nepal Terai.

years, with an average age of 17 years. A total of $60 \%$ of the surveyed mills were established in the past 20 years or more while only $12 \%$ mills were established in last five years. Results indicated that rice millers opted for medium and larger mills in recent years over the smaller ones. It was also interesting that $45 \%$ of all the rice mills established in last 10 years were concentrated in the Central Terai (Table 1).

\subsection{Rice Milling Operations}

Discussion with rice millers it was revealed that rice processing by millers involves de-stoning, de-husking, polishing, grading, and packaging. The quality of rice grains obtained from large mills is better than that from small mills as the large mills have adopted modern technologies, including a de-stoner, a separator, and grading facilities.

On the basis of type of technology, approximately $80 \%$ of the surveyed mills were fully automatic while the remaining $20 \%$ were semi-automatic and conventional.

Mills from the Eastern and Central clusters contributed approximately $80 \%$ of the total volume of rice processing. Small- and medium-sized mills were operating less than 7 months a year while the large mills were operating 9 months a year (Table 2).

Milling operation decreases when moving from the Eastern Terai to Western Terai. Out of 50 mills, 17 mills operate less than 6 months and most of them are relatively old and small to medium in size. Twenty-one mills operate from 6 to 9 months. Only 12 mills operate for more than 9 months in a year (Table 3 ).

\subsection{Milling Capacity and Efficiency of Operations}

On average, the rice mills were operating at $55 \%$ of their capacity. Rice milling efficiency of the Eastern cluster was highest (69\%) and milling efficiency decreases gradually from the Eastern Terai to Western Terai. In the Western cluster, 
Table 1. Summary of rice mills in Nepal Terai on the basis of milling capacity and year of establishment.

\begin{tabular}{|c|c|c|c|c|c|c|c|c|c|c|c|c|}
\hline \multirow{3}{*}{$\begin{array}{l}\text { Study } \\
\text { cluster }\end{array}$} & \multicolumn{12}{|c|}{ Age of rice mills } \\
\hline & \multicolumn{3}{|c|}{ Up to 5 years } & \multicolumn{3}{|c|}{$6-10$ years } & \multicolumn{3}{|c|}{$11-19$ years } & \multicolumn{3}{|c|}{ More than 20 years } \\
\hline & Large & Medium & Small & Large & Medium & Small & Large & Medium & Small & Large & Medium & Small \\
\hline Eastern Terai & 0 & 0 & 1 & 1 & 0 & 1 & 1 & 1 & 4 & 2 & 4 & 0 \\
\hline Central Terai & 3 & 0 & 2 & 1 & 1 & 2 & 0 & 3 & 1 & 2 & 0 & 1 \\
\hline Western Terai & 0 & 2 & 1 & 1 & 4 & 0 & 0 & 1 & 3 & 1 & 5 & 1 \\
\hline Total & 3 & 2 & 4 & 3 & 5 & 3 & 1 & 5 & 8 & 5 & 9 & 2 \\
\hline
\end{tabular}

Table 2. Size of rice mills and their average annual operations in the study area.

\begin{tabular}{cccccccc}
\hline \multirow{2}{*}{$\begin{array}{c}\text { Study } \\
\text { cluster }\end{array}$} & $\begin{array}{c}\text { Number } \\
\text { of mills }\end{array}$ & \multicolumn{3}{c}{$\begin{array}{c}\text { Average milling per year } \\
\text { (t/year) }\end{array}$} & \multicolumn{3}{c}{$\begin{array}{c}\text { Average annual operations } \\
\text { (months) }\end{array}$} \\
\cline { 3 - 8 } & & Small & Medium & Large & Small & Medium & Large \\
\hline Eastern & 15 & 564 & 4340 & 14,613 & 6 & 8 & 9 \\
Central & 16 & 1047 & 2667 & 10,167 & 8 & 7 & 9 \\
Western & 19 & 701 & 1923 & 7825 & 7 & 7 & 10 \\
Average & 17 & 738 & 2642 & 11,258 & 7 & 7 & 9 \\
\hline
\end{tabular}

Table 3. Rice mill operation per year.

\begin{tabular}{ccccc}
\hline Mill operation & Eastern & Central & Western & Total \\
\hline Less than 4 months & 1 & 0 & 3 & 4 \\
$4-6$ months & 2 & 6 & 5 & 13 \\
7 - 9 months & 9 & 5 & 7 & 21 \\
More than 9 months & 3 & 5 & 4 & 12 \\
Total & $\mathbf{1 5}$ & $\mathbf{1 6}$ & $\mathbf{1 9}$ & $\mathbf{5 0}$ \\
\hline
\end{tabular}

the mills were operating with the least efficiency (38\%), which means that they face a high risk of closure (Table 4).

The Eastern Terai is the main hub for the rice milling industry because three districts (Jhapa, Morang, and Sunsari) contain nearly $20 \%$ of nearly 1.48 million ha rice area of Nepal, with some area under double rice cropping as Chaite (spring) season rice coupled with high rice productivity. Nearly $41 \%$ of the 206,955 tons of rice was milled in the Eastern Terai while the share of the Central Terai was nearly $38 \%$ and that of the Western Terai $21 \%$ (Table 4 ).

\subsection{Commercial Rice Varieties}

The rice varieties that are preferred by farmers and processors and therefore adopted at a reasonable scale usually arrive for milling and processing. A total of 31 rice varieties were reported to have been milled by their original names in the survey (Table 5 and Table 6 ). Rice varieties that were not sold by their original 
Table 4. Summary of paddy milling capacity, annual transactions, and efficiency of surveyed rice mills in Nepal.

\begin{tabular}{cccccc}
\hline $\begin{array}{c}\text { Study } \\
\text { cluster }\end{array}$ & $\begin{array}{c}\text { Number } \\
\text { of mills }\end{array}$ & $\begin{array}{c}\text { Total milling } \\
\text { capacity } \\
\text { (t/year) }\end{array}$ & $\begin{array}{c}\text { Quantity of } \\
\text { paddy milled } \\
\text { (t/year) }\end{array}$ & $\begin{array}{c}\text { Actual } \\
\text { throughput } \\
\text { per mill (t/year) }\end{array}$ & $\begin{array}{c}\text { Efficiency of } \\
\text { rice mill } \\
\text { operations (\%) }\end{array}$ \\
\hline Eastern & 15 & 120,500 & $83,536(41 \%)$ & 5570 & 69 \\
Central & 16 & 142,300 & $81,190(38 \%)$ & 5074 & 57 \\
Western & 19 & 110,695 & $42,229(21 \%)$ & 2223 & 38 \\
Total & $\mathbf{5 0}$ & $\mathbf{3 7 3 , 4 8 0}$ & $\mathbf{2 0 6 , 9 5 5 ( 1 0 0 \% )}$ & $\mathbf{4 1 3 9}$ & $\mathbf{5 5}$ \\
\hline
\end{tabular}

Table 5. Rice varieties reported during the survey by rice millers as identified by variety names and grain quality ${ }^{1}$.

\begin{tabular}{|c|c|c|c|c|c|c|c|}
\hline $\begin{array}{c}\text { Varieties } \\
\text { with short } \\
\text { coarse grain }\end{array}$ & $\begin{array}{c}\text { Year } \\
\text { of } \\
\text { release }\end{array}$ & $\begin{array}{c}\text { Varieties } \\
\text { with } \\
\text { medium grain }\end{array}$ & $\begin{array}{c}\text { Year } \\
\text { of } \\
\text { release }\end{array}$ & $\begin{array}{l}\text { Varieties with } \\
\text { medium } \\
\text { fine grain }\end{array}$ & $\begin{array}{c}\text { Year } \\
\text { of } \\
\text { release }\end{array}$ & $\begin{array}{l}\text { Varieties } \\
\text { with fine } \\
\text { grain }\end{array}$ & $\begin{array}{l}\text { Year of } \\
\text { release }\end{array}$ \\
\hline IR8 & 1968 & Sona & $\mathrm{NR}^{*}$ & Ramdhan & 2006 & Basmati & (Landrace) \\
\hline Radha-12 & 1994 & Hybrid-6201 & 2011 & Sabitri & 1979 & $\begin{array}{c}\text { Rato } \\
\text { Basmati }\end{array}$ & 2010 \\
\hline Radha-4 & 1994 & Super (Hybrid) & NR & Ram Bilash & NR & Mansuli & 1973 \\
\hline Mota & NR & Mala hybrid & 2015 & Ranjit Mansuli & NR & $\begin{array}{c}\text { Sawa } \\
\text { Masuli-Sub1 }\end{array}$ & 2011 \\
\hline Silki & NR & $\begin{array}{l}\text { Kanchhi } \\
\text { Mansuli }\end{array}$ & NR & Sonam & NR & Sinduri & 2015 \\
\hline Bhadaiya & NR & Hardinath-1 & 2004 & Gorakhnath & 2011 & $\begin{array}{c}\text { Kalo } \\
\text { Nuniya }\end{array}$ & (Landrace) \\
\hline $\begin{array}{l}\text { Coarse } \\
\text { (hybrid) }\end{array}$ & NR & Swarna-Sub1 & 2011 & Katarni & NR & Jira Masino & NR \\
\hline Sarju-52 & NR & & & IR24 & 1975 & Karma & NR \\
\hline
\end{tabular}

${ }^{\star} \mathrm{NR}=$ not released.

Table 6. Rice varieties reported in the study with their geographic coverage and quantity of rice milled.

\begin{tabular}{ccccc}
\hline Rice variety & $\begin{array}{c}\text { Rice grain } \\
\text { quality }\end{array}$ & $\begin{array}{c}\text { Number } \\
\text { of mills } \\
\text { reporting }\end{array}$ & $\begin{array}{c}\text { Quantity } \\
\text { milled } \\
\text { (t/year) }\end{array}$ & $\begin{array}{c}\text { Terai cluster } \\
\text { where } \\
\text { commonly } \\
\text { grown }\end{array}$ \\
Sona & Medium & 24 & 40,118 & East, Central, West \\
Katarni & Medium fine & 15 & 25,100 & East, Central \\
Gorakhnath & Medium fine & 8 & 23,016 & East, Central, West \\
Mansuli & Fine & 15 & 21,670 & East, West \\
\hline
\end{tabular}

${ }^{1}$ Grain quality is determined on the basis of grain length and shape. Brown rice length after dehulling before milling; extra-long $=$ more than $7.5 \mathrm{~mm}$, long $=6.6$ to $7.5 \mathrm{~mm}$, medium $=5.51$ to $6.6 \mathrm{~mm}$, short $=5.5 \mathrm{~mm}$ or less. Brown rice shape after dehulling before milling (length-width ratio); slender over 3 , medium $=2.1$ to 3 , bold $=1.1$ to 2.0 and round $<1.1$. 


\begin{tabular}{ccccc} 
Continued & & & & \\
\hline Ranjit Mansuli & Medium fine & 10 & 19,486 & East, West \\
Sarju-52 & Coarse & 13 & 16,986 & East, West \\
Kanchhi Mansuli & Medium & 8 & 11,111 & East, West \\
Radha-4 & Coarse & 12 & 9511 & West \\
Sonam & Medium fine & 3 & 9250 & Central, West \\
Jira Masino & Fine & 5 & 6350 & East, Central, West \\
Sawa Masuli-Sub1 & Fine & 4 & 5175 & East, Central, West \\
Basmati & Fine and aromatic & 7 & 5100 & East, Central, West \\
Hardinath-1 & Medium & 4 & 2640 & East, Central, West \\
Sabitri & Medium fine & 10 & 2124 & Central, West \\
Radha-12 & Coarse & 6 & 1877 & East, Central \\
Swarna-Sub1 & Medium & 3 & 850 & East, Central \\
Other coarse grain & Coarse & 10 & 4411 & East, Central, West \\
Other medium fine grain & Medium fine & 3 & 1800 & East, Central, West \\
Other medium grain & Medium & 5 & 1550 & East, Central, West \\
Other fine grain & Fine & 4 & 975 & East, Central, West \\
\hline
\end{tabular}

names as recommended by the Variety Release and Registration Committee of Seed Quality Control Centre (SQCC) may be missing from or mis-represented on this list as such varieties may be coming for milling in some other name as branded by the millers.

The results may seem unexpected in that very old varieties such as IR8 and IR24 are still grown and milled in Nepal. Only 6 out of 31 rice varieties reported in the study were new varieties that were released after 2010. Three varieties (Basmati, Rato Basmati, and Kalo Nuniya) are aromatic landraces and have a high market value in comparison with other varieties. More than $50 \%$ of the commercial rice that arrived for milling is from varieties not released in Nepal by the SQCC, including landraces. Although 31 varieties have been listed to be milled in the study area, not all of these are of equal importance in terms of volume of their transactions. Table 5 lists the dominant varieties by type of rice. The results are a mirror image of overall rice research and development in Nepal, including variety popularization and marketing and the prevalent seed systems in the country.

Coarse rice varieties cover nearly $42 \%$ of the total milled rice in Nepal. The share of medium rice was $34 \%$ while that of medium fine varieties was $17 \%$. Fine rice varieties, on the other hand, comprised less than $7 \%$ of the total volume of rice milled in the study area. The study did not come across even a single case of long and extra-long slender rice varieties being milled in the surveyed area. Most 
of the rice varieties grown in the hilly areas are medium to fine varieties and milled locally. Any farmer growing long grain varieties also goes to similar mills that mill medium grain fine rice with low head rice recovery.

\subsection{Catchment Area of Paddy and Rice Demand}

The study also looked at the popularity of rice varieties in the rice industry in Nepal. Based on the quantity of rice milled, coarse, medium fine, medium, and fine varieties are the most popular (Table 6). Most of the popular varieties are old and widely adopted ones, whereas Sawa Masuli-Sub1, released in 2011, is also becoming one of the most popular varieties released in the past 10 years, which indicates high potential growth for this variety.

Table 6 depicts that Sona, although it is a medium coarse grain rice, was milled by about half of the rice millers, covering a $20 \%$ share by quantity, followed by Katarni and Gorakhnath, with a $12 \%$ and $11 \%$ market share, respectively. Table 5 and Table 6 show that high-yielding fine or medium fine varieties promoted by the national rice processing system are dominated by non-registered, traditional, or Indian medium fine varieties such as Sona, Katarni, Gorakhnath, and Ranjit Masuli. Among the formally released varieties, Mansuli, Sawa Masuli Sub1, and Rdha-4 and Sabitri were more commonly reported. Similarly, Kalo Nuniya, Ram Bilash, Ranjit Masuli, and Sinduri were reported from just one cluster only.

It is interesting that out of 12 rice varieties reported in this survey are the same varieties reported as top 15 most popular varieties in Nepal by an earlier study done by Crop Development Directorate, Department of Agriculture Nepal [4]. This also indicates that rice varietal portfolio has little changed since 2015. Three rice varieties not detected in the present study were Khumal-4 (grown only in the hills), Makwanpur-1, Ramdhan. Makwanpur-1 has a localised adoption and Ramdhan may have been promoted in the popular brand name such as Jira Masino by the millers.

Contract farming was not practiced by any of the mills surveyed. Almost all of the large and medium mills (23 out of 24) procure paddy from 100 to $700 \mathrm{~km}$ away while most of the small mills procure it from nearby areas (within $90 \mathrm{~km}$ ). This may be because Nepal does not have adequate production of a specific variety and most of the farmers are small in operations and have a low marketable surplus.

When domestic paddy is no longer available, rice mills import paddy from India mainly through Bhairahawa and Birgunj border points in Nepal through informal (illegal) trade. According to the millers, this takes place without any documentation at the customs point. Also, fine and long slender parboiled rice are imported by traders and rice millers mainly from India via all borders through formal as well as informal ways. All the mills decide on the variety and type of rice to be imported based on demand in the domestic 
market. Also, we found that some rice millers were engaged in importing and trading parboiled rice because their mills remain closed for most time of the year.

Imports of Basmati rice have continued to surge in recent years. According to rice traders, approximately 2000 tons of rice enter Nepal daily from India. This is discounting the rice smuggled into Nepal through rural areas with illegal porous borders. Rice imports surged after India lifted the ban on rice and paddy exports to South Asian Association for Regional Cooperation (SAARC) countries. This led to Nepali markets being flooded with cheaper and inferior-quality Indian rice. In 2015-16, the annual imports were valued at Nepalese Rupees (NPR) 10.20 billion (USD 96.201 million using an exchange rate of 1 US dollar is 106.0280). In 2015-16, rice imports jumped 66\% despite the country recording a bumper paddy harvest (21.6\% increases) [13].

The demand for coarse rice is much higher in the hills and Southern Terai area. Consumers of coarse rice usually demand local rice at a cheaper price. Also, the price of coarse rice varies among mills and locations on the basis of competition, variety, and broken rice percentage. So, more than $90 \%$ of the coarse rice found in the market is locally produced while fine and parboiled rice are fulfilled mainly by imports from India.

Rural Terai countryside consumers demand relatively cheaper medium to medium fine rice, hill people demand cheaper coarse to medium grain quality rice. However, urban consumers demand fine, aromatic, medium fine, and parboiled rice. Demand and preference for long slender and parboiled rice are also noted for a few Terai and urban consumers. Similarly, rice millers are supplying relatively expensive aromatic Basmati-type and high-quality fine rice in Pokhara and Kathmandu markets.

Once a rice-exporting country, Nepal started importing rice in the early $1980 \mathrm{~s}$ and rice imports increased by more than fourfold from 144,042 tons in 2010 to 607,690 tons in 2014 (Figure 2).

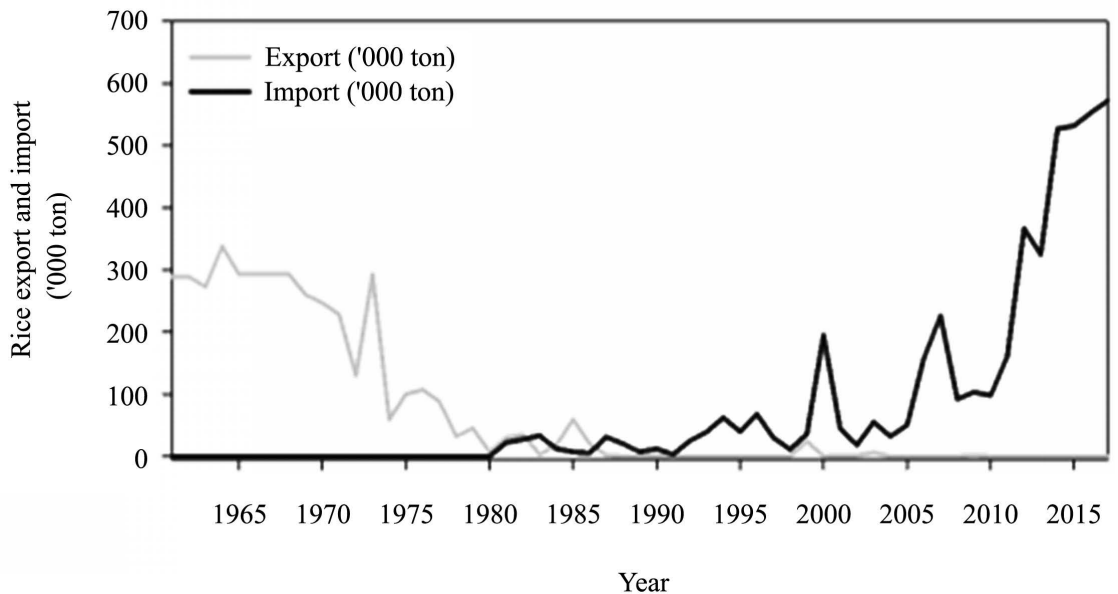

Figure 2. Rice imports and exports during 1961-2015 [14]. 


\subsection{Price Regime of Rice}

Figure 4 indicates that, in 2018, medium fine and fine rice were traded at NPR 45 - 55 per kg, while coarse and medium rice fetched only NPR 35 - 42 per kg. As the market share of fine and quality rice is gradually increasing, the price also increases, and the price of fine grain paddy is slightly higher than the price of coarse and medium grain paddy. Also, for aromatic rice, the price surpasses NPR 80 per kg.

In comparing the price of paddy and rice with that of 2008, the price ranged from NPR 12 to 20.5 for paddy and from NPR 19 to 36 per $\mathrm{kg}$ for rice, while in 2018 the price ranged from NPR 21.5 to 50 for paddy and from $\mathrm{NPR}^{2} 33$ to 90 per kg of rice (Figure 3 and Figure 4). In comparison to 2008, the price increase in 2018 for both paddy and rice was $60 \%$ higher for popular rice varieties such as Radha-4, Gorakhnath, Sona, Ram Bilash, Katarni, and Basmati types (Figure 4). From Figure 4, we can conclude that the price increase for fine and aromatic rice is higher than the price increase for coarse and medium rice, which may be because of an increased demand for fine rice due to an increase in choices and income of consumers.

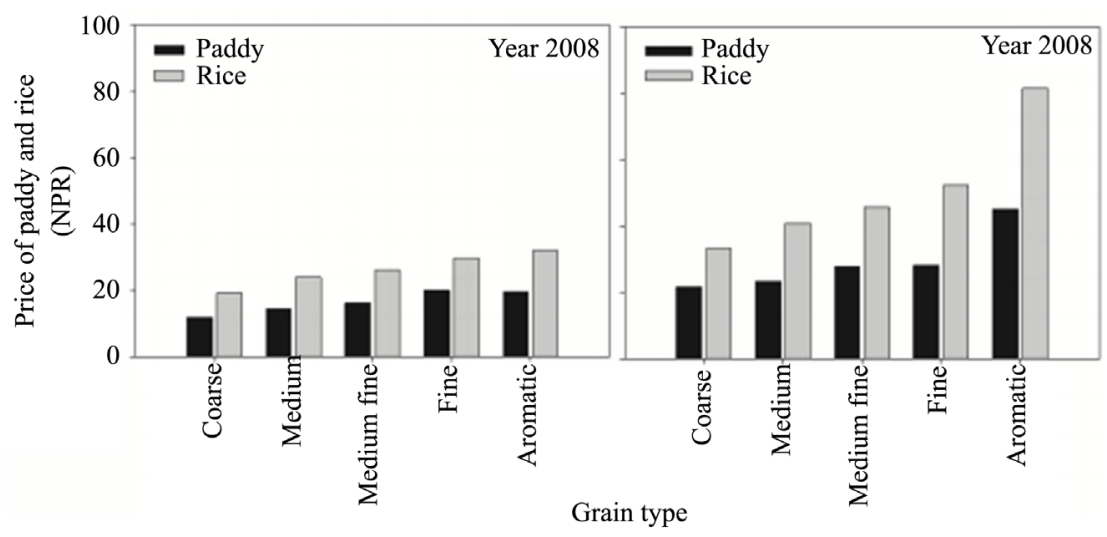

Figure 3. Average price of paddy and rice by grain type.

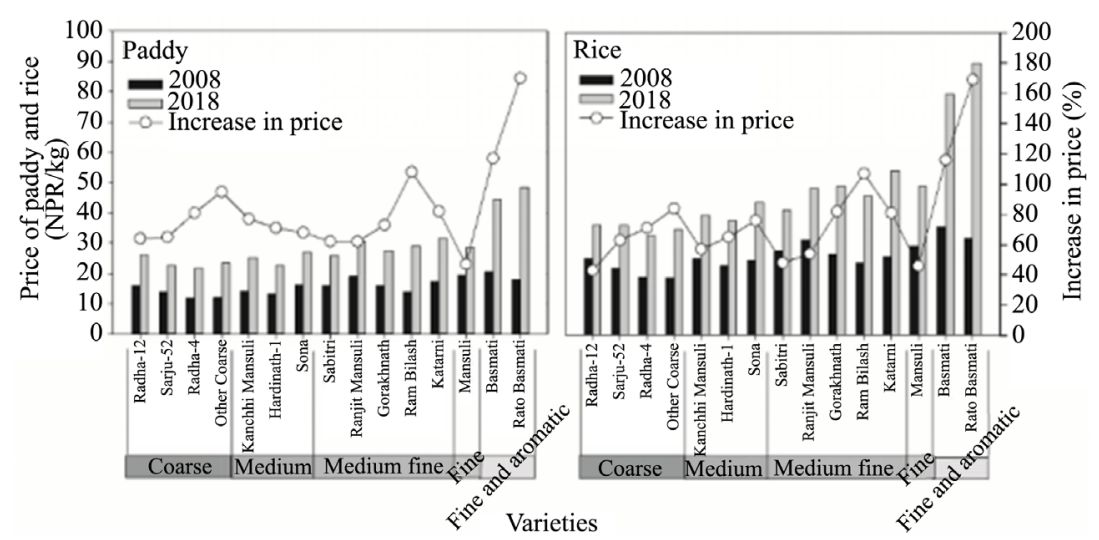

Figure 4. Analysis of price trends of 2008 and 2018 for paddy and rice based on grain quality.

${ }^{2} 1$ USD =106.795 NPR in April-May 2018. 
None of the rice mills reported having milled long and extra-long grain rice. The difference is less marked between the coarse and medium category of rice for their price while the price for a few of the fine and premium-quality rice varieties was more than double that of coarse grain rice (Figure 4 ). The study also documented that few of the fine rice varieties are purchased by millers at a price similar to that of coarse or medium grain varieties, but they are sold at a very high price.

The difference between the price of paddy and milled rice was high and this is an indication of a poorly developed rice value chain. Farmers are obtaining only inadequate benefits from rice because, in 13 out of 16 cases, the farmers received less than $50 \%$ of the price benefit and, in most cases, this figure was from $30 \%$ to $45 \%$, while the millers and retailers were making the most profit from the rice industry. New, high-yielding, stress-tolerant, short-duration varieties with fine grain quality have good potential for benefiting both producers and the processing industry.

Also, analysis showed that steamed or parboiled rice obtained more of a premium price than conventionally milled rice of the same variety because of good branding, attractive packaging, unbroken grains, and cleanliness.

\subsection{Milling Recovery and Efficiency of Rice Mills}

The performance of modern rice mills was far superior to that of obsolete rice mills for all the parameters studied (Table 7). It is unsurprising why conventional rice mills have been shutting down their business for the past few years. Small mills using older technology were mainly operating as service providers in the rural areas. The main reasons cited for the downfall of such mills were the outdated processing technology as a result relatively inferior-quality product and lack of enough paddy from service seekers, and they ultimately failed to compete with imported and attractively branded rice produced in automated modern rice mills [15].

\subsection{Cost of Rice Milling}

The average cost for milling of Arwa rice varies by the type of rice (Table 8). The milling cost of $A r w a^{3}$ rice is NPR 1.6 per kg, ranging from NPR 1.3 to 2.0 per kg, while the cost of parboiled rice is NPR 2.4 per $\mathrm{kg}$. The cost of storage, loading,

Table 7. Milling recovery and weight loss in conventional and modern rice mills.

\begin{tabular}{cccccc}
\hline Mill type & $\begin{array}{c}\text { Milling } \\
\text { outturn } \\
(\%)\end{array}$ & $\begin{array}{c}\text { Husk } \\
(\%)\end{array}$ & $\begin{array}{c}\text { Rice bran } \\
(\%)\end{array}$ & $\begin{array}{c}\text { Brokens } \\
(\%)\end{array}$ & $\begin{array}{c}\text { Weight } \\
\text { loss } \\
(\%)\end{array}$ \\
\hline Husky (obsolete) & $60-65$ & $20-25$ & $8-10$ & $5-10$ & $0-10$ \\
Automatic modern & $60-70$ & $17-22$ & $5-10$ & $5-7$ & $0-10$ \\
\hline
\end{tabular}

${ }^{3}$ Polished rice is known as Arwa in the vernacular and it is produced first by de-husking paddy to produce brown rice, which is then polished using a rice polisher. 
Table 8. Cost of milling by rice type.

\begin{tabular}{ccc}
\hline \multirow{2}{*}{ Type of rice } & \multicolumn{2}{c}{ Price of milling (NPR per kg) } \\
\cline { 2 - 3 } & Range & Average \\
\hline Coarse & $1.10-2.19$ & 1.53 \\
Medium & $0.50-2.04$ & 1.38 \\
Medium fine & $1.25-1.67$ & 1.46 \\
Fine & 2.00 & 2.00 \\
Parboiled/steamed & $2.00-3.50$ & 2.75 \\
\hline
\end{tabular}

and unloading is not included as the analysis considers just the milling cost. The storage cost of large mills is higher than that of small mills as they require a large investment in a warehouse with huge floor space. Also, the cost accounts for the level of technology and machines used in the industry. The cost of parboiled rice is higher than that of Arwa rice but the parboiled rice is much cleaner and unbroken.

\subsection{Addressing Changing Demand for Rice}

Health consciousness is increasing in Nepalese society and consumers are looking for fresh and healthier rice such as locally produced Basmati, Himalayan red rice (Marshi), brown rice, and parboiled rice. Organic shops and online outlets are responding to some of this demand. Demand for long rice, extra-long slender rice, and aromatic rice is ever increasing and is mainly met through imports from India. Some interventions are deemed necessary to address the changing rice demand in Nepal. In our study, $50 \%$ of the millers suggested upgrading current milling technology, $22 \%$ of the millers suggested promoting currently demanded rice varieties, while a similar proportion of the millers suggested that appropriate rice varieties and milling technologies should be promoted simultaneously.

For necessary improvement in milling technology, 33\% of the rice millers opted to introduce technology appropriate for milling long and extra-long slender rice, $30 \%$ suggested replacing conventional rice mills to produce steamed or parboiled rice, and the remaining millers were interested in upgrading the capacity of fine rice milling technology. In the case of changing rice varieties for commercial purposes, nearly half of the millers were interested in fine rice, $9 \%$ in long, extra-long slender rice, whereas about $40 \%$ of the millers were happy to focus on medium and coarse grain rice. Technology for parboiling rice in milling was concentrated in Eastern and Central Nepal.

\section{Discussion}

The rice milling industry is the key infrastructure shaping the rice value chain in Nepal. The study indicated a predominance of old rice varieties in the processing industry. Earlier studies also indicated the predominance of old and popular va- 
rieties in rice production system of Nepal due to delay in variety testing, release and popularization [4] [16] [17] [18]. This is because millers prefer to deal in as few varieties as possible and subsequently those rice varieties get the priority which have higher economies of scale, and generally these tend to be older varieties [16]. Growing old and obsolete varieties has a big cost to the societies. This is because farmers fail to gain the benefits of growing newer varieties that have had more generations of plant breeding improvement (genetic gains) [17].

The adoption patterns of rice varieties and technology of the rice mill also determine the type of rice varieties that can or cannot be commercialized. For example, long and extra-long rice varieties are yet to be established as commercial opportunities mainly because of the lack of an appropriate milling industry in the country. All the popular long and extra-long rice grown in Haryana and Punjab of India and Punjab of Pakistan can be profitably grown in Nepal considering the similarity in agro-ecological conditions; nevertheless, the lack of appropriate milling technology and absence of other elements in place for this change are the main obstacles.

The rice market is highly specialized and, for new varieties to be able to find a market share, this will depend on many factors such as the scale of the operations, consumer demand, a good match between rice varieties and rice milling technology, and horizontal and vertical coordination.

Our study showed that none of the rice varieties released recently have been reported by millers except for Sawa Masuli-Sub1. This meant that either these varieties are in early stages of adoption or they are sold in the market with some other name. This requires high priority in popularizing newly released rice varieties with their varietal identity. Demand for and popularity of the new varieties can be created in society by highlighting their cooking and eating quality, taste, and potential market price, and popularizing them by engaging with all the major actors of the rice value chain in all the exercises done to achieve this output. The study also revealed that popular rice varieties with substantial volumes of transaction are often recognized by their popular names which can be both official names, e.g. Hardinath-1, Radha-4 and Radha-12 and Kanchhi Mansuli, Sona, Sonam, Katarni-names given by millers or producers.

Rising varietal age is associated with declining marginal returns to plant breeding. Estimates of varietal turnover that exceed 20 years indicate that more recent varieties are having a hard time competing with earlier varieties. This also holds well in case of rice varietal replacement in Nepal [16] [17] [18].

Premium rice from India fetches a very high price in Nepal markets and it is a general perception that rice produced and processed in Nepal is not of the same quality standard as that coming from India. The Nepalese rice industry has ample opportunity to counteract this myth and model rice processing and branding as per the emerging consumer demand. Several of the newly released rice varieties not only conform to international standards in terms of quality parameters but also are high yielding with multiple stress tolerance to make the rice industry 
profitable and competitive.

It is high time for the government of Nepal to critically review current demand against the existing scenario and understand the interest and willingness of rice millers to invest in upgrading their rice mills to be able to mill long and extra-long rice and/or install mills for special-purpose rice milling, for example, for steamed rice. This is a strategic decision in counteracting the ever-increasing rice imports into Nepal.

\subsection{Major Constraints of Nepalese Rice Millers}

The major constraints faced by the rice milling industry are largely related to its composition. Large variations exist in type, milling capacity, storage capacity, processing efficiency, technology, services rendered, as well as ownership of different processing units. Consequently, the investment requirement and costs and returns also vary over a wide range. Technical capacity is not fully used for various reasons: short supply of paddy to meet demand, limited skills and capacity of the workforce in the processing industry, and shortage of skilled and semi-skilled labor during peak operation periods.

The following are the major constraints affecting Nepalese rice millers:

1) Limited rice varietal choice and established milling technology for long and extra-long slender rice in Nepal.

2) Only a few steamed and parboiled rice processing machines were introduced in Nepal for high throughput processing for high milling quality. These mills still rely on India for raw materials and skilled manpower.

3) Lack of enough funds to invest during operations (for purchasing of raw paddy, payment for labor, etc.). Bank loans require rigorous documentation for loan processing. Also, the high interest rate of banks hinders rice millers and traders from borrowing money from financial institutions. Longer waiting period for payment by traders

4) New generations are neither interested in agricultural production nor in agri-business; rather are opting for higher studies or foreign employment. Therefore, family businesses established long ago are also at risk of closure or they are managed by senior citizens.

5) Lack of corporate culture with rice processing industries in Nepal is common. Most of the proprietors want to sell their mill and stop the business rather than converting these into a corporate set up.

6) Shortage of local skilled, semi-skilled, or unskilled labor.

In the past four years, 250 out of 300 rice mills in Bara and Parsa districts have shut down mainly because of the lack of paddy in the country as well as imports of subsidized rice from India [19]. For example, most of the rice millers in Jhapa and Morang import cheaper rice and packaging under various brands [20]. The rice milling industry faces high competition with the Indian rice industry; as a result, 500 rice mills out of 1500 reported to have been shut down in the country [21]. Rice mills employ approximately 26,000 people across the country and 
their closure threatens large numbers of jobs [22].

Following are the major reasons for the closure of conventional mills:

1) Low profit margin in rice milling. Although the margin remains high in selling imported premium-quality rice from India instead of milling imported paddy, rice millers prefer to import fine and long slender rice rather than coarse rice.

2) Lack of a competitive advantage of local fine rice over branded imported products. The Nepalese market is competitive with coarse rice from India.

3) Aggressive marketing of various brands of steamed and parboiled long slender rice by the media captured the attention of the urban market through stalls in shopping complexes.

4) Lack of proper quality standard grading and branding in locally produced rice. The percentage of brokens rice, husk and bran is high at times milled rice comes with a mixtures of different varieties. Lack of proper postharvest handling, cleaning, and grading results in low head rice recovery with low milling efficiency.

5) Unhealthy competition/cartel among rice millers, resulting in high price fluctuations of raw paddy and processed rice in the market.

6) The porous border between Nepal and India encourages brokers to export paddy to India via informal routes and import branded fine and long slender rice into Nepal illegally or with minimal customs duty.

7) Ambiguous policy for tariffs and taxes on raw and fine rice for imports and exports.

\subsection{Opportunities}

\subsubsection{Focusing on the Emerging Demand of New Rice Varieties and Their Productivity}

Increasingly, demand for fine and medium fine varieties is increasing in the country and this category of rice is demanded by the largest proportion of population in Nepal (middle income group) while the demand for long slender, aromatic rice is also increasing but their total requirement will be modest. Nevertheless, these two categories of rice will fetch highest profit margins for the producers and millers should there be a horizontal and vertical coordination in the rice value chain [13] [14]. Current rice productivity is just $3.67 \mathrm{t} / \mathrm{ha}$. The growing of high-yielding multi-stress-tolerant rice varieties with diverse grain quality including those developed recently by the International Rice Research Institute and other national and international partners is of strategic importance in terms of addressing rice self-sufficiency in Nepal. Such varieties tested and released by the national programme in Nepal need to be grown using best management practices that could raise rice productivity up to $5 \mathrm{t} / \mathrm{ha}$. Several irrigation projects are under construction, which are in potential areas for growing two crops of rice in a year. Nevertheless, technology-intensive rice farming is mandatory to achieve higher productivity growth of rice in Nepal. 
Nepal also has a considerable number of premium quality rice landraces that can be promoted using their Geographic Indication to cater for the needs of the consumers.

\subsubsection{Adoption of High Throughput Parboiling and Steamed Rice Processing Technology}

Parboiled and steamed rice have better nutritive value than polished rice because of the migration of vitamins from the outer layers of the rice kernel into the inner starchy endosperm. Moreover, these techniques increase milling percentage up to $72 \%-73 \%(2 \%-8 \%$ more than for white polished rice) and whole rice outturn of $60 \%-65 \%$ ( $20 \%-30 \%$ more than for while polished rice) mainly by decreasing the proportion of broken rice and bran considerably. Parboiling and steaming could perhaps offer the easiest and cheapest method of achieving rice self-sufficiency in Nepal. Interaction with the rice millers it was revealed that health conscious affluent consumers are increasingly using parboiled and steamed rice.

\subsubsection{Improving Harvesting and Post-Harvest Handling of Rice}

It is estimated that up to $10 \%$ of the paddy/rice is damaged or lost due to weight loss in drying, transportation, processing, and storage with the existing technology. Improvements in postharvest handling and storage facilities could decrease this loss by protecting the grain from spontaneous heating, moisture, fungal damage, and damage by birds, rodents, and insects.

It is customary in Nepal to leave rice to dry in standing condition until the rice straw also is fully dried. This exposes rice grain to sun cracking and these results in high breakage during the milling. After harvesting the crop, grains are again sun dried. This is most common traditional method of drying, which is fully weather dependent and also requires the construction of large floor area for drying restricting the capacity of a mill to a certain extent. Significant losses also occur during the drying and cleaning processes.

Rice milling industry in Nepal need to explore the possibility of introducing electric dryers, solar dryers to encourage harvesting rice before grains get sun cracking as well as to reduce the loss during drying process.

\subsection{Recommendations for Interventions}

The following recommendations are strategic for the overall improvement of rice sector including rice processing industry in Nepal:

1) Priority should be given to the commercialization of recently released (as rice production systems in Nepal are dominated with old and obsolete varieties) multi-stress-tolerant, high-yielding, fine, medium fine, long, and extra-long slender rice varieties using best management practices and precision rice farming to produce enough marketable surplus to cater to the needs of Nepal's rice milling industry.

2) High-yielding and high-value local rice landraces should be promoted 
through geographical indication (GI) to decrease rice imports.

3) The rice processing industry could be upgraded by introducing modern, appropriate, cost-effective milling and drying technologies.

4) Developing capacity of rice processing industry in high throughput milling for processing steamed, parboiled and polished rice including developing the skilled workforce in packaging and branding.

5) A scientific pricing policy should be established considering the grain quality of rice to motivate rice farmers to grow rice varieties in demand.

6) In-country capacity for high-quality processing and branding of steamed and parboiled rice should be developed, while also developing other rice products to diminish rice imports and create new rice-based enterprising opportunities in the country.

7) An appropriate national rice strategy and policies should be developed considering the political economy of rice in Nepal.

8) Since the study was focused on the rice millers, it was difficult to know the extent of marketable surplus available for milling by the type of rice varieties. Hence, a study on quantifying the volume of marketable surplus by rice varieties and by agro-ecoogical regions will be important for contributing to develop a practical rice strategy of Nepal.

\section{Acknowledgements}

We thank the dozens of rice processing companies for their collaboration and valuable contributions in this research. We acknowledge the project partners, including Nepal Agricultural Research Council, the Department of Agriculture, and Ministry of Agriculture and Livestock Development. Ayush Joshi prepared the map for the article.

\section{Funding}

The authors thank Bill and Melinda Gates Foundation for providing financial support for this research through the project Stress Tolerant Rice for Africa and South Asia.

\section{Conflicts of Interest}

The authors declare no conflicts of interest regarding the publication of this paper.

\section{References}

[1] Tripathi, B., Bhandari, H.N. and Ladha, J.K. (2019) Rice Strategy for Nepal. ACTA Scientific Agriculture, 3, 171-180.

[2] Ministry of Agriculture and Development (2020) Agribusiness Promotion and Statistics Division, Kathmandu, Nepal.

[3] Central Bureau of Statistics (2016) National Economic Census 2018: A New Initiative in the National Statistical System of Nepal. Central Bureau of Statistics, Nation- 
al Planning Commission, Kathmandu.

[4] Crop Development Directorate (2015) Rice Varietal Mapping in Nepal: Implications for Development and Adoption. Crop Development Directorate, Department of Agriculture, Harihar Bhawan, 90.

[5] Department of Customs (2018) Nepal Foreign Trade Statistics Fiscal Year 2017-18 (2074/75). Department of Customs, Ministry of Finance, Government of Nepal, Kathmandu, 705.

[6] Central Bureau of Statistics (2019) Report on the Nepal Labour Force Survey, 2017/18. National Accounts 2018/19, Central Bureau of Statistics, Kathmandu.

[7] Asian Development Bank (2019) Proposed Policy-Based Loan and Technical Assistance Grant Nepal: Food Safety and Agriculture Commercialization Program. Asian Development Bank, Manila, 16 p.

[8] Gurung, G.B., Khanal, N.P., Sapkota, A., Bhandari, B. and Upreti, A. (2010) Value Chain Analysis of Rice in Rupandehi District. Forum for Rural Welfare and Agricultural Reform for Development (FORWARD Nepal), Bharatpur, 28 p.

[9] Thapa, T.L., Bhattarai, C., Khatri, B. and Bhusal, K. (2018) Supply Chain Analysis of Rice Sub-Sector in Dang District, Nepal. International Journal of Applied Sciences and Biotechnology, 6, 319-326 https://doi.org/10.3126/ijasbt.v6i4.22109

[10] The Asian Development Bank and the International Rice Research Institute (2019) Climate-Smart Practices for Intensive Rice-Based Systems in Bangladesh, Cambodia, and Nepal.

https://www.adb.org/sites/default/files/publication/533186/climate-smart-rice-syste ms-ban-cam-nep.pdf

[11] Pavithra, S., Singh, K.M., Ahmad, N., Sinha, D. and Mishra, R. (2017) Analysis of Rice Value Chains-A Study of Bihar and Karnataka States in India. SSRN Electronic Journal. https://doi.org/10.2139/ssrn.3058145

[12] Vikaspedia (n.d.). https://vikaspedia.in/agriculture/post-harvest-technologies/technologies-for-agri-ho rti-crops/rice-milling-plant-process

[13] The Kathmandu Post (2018). https://kathmandupost.com/money/2018/03/19/demand-for-basmati-spikes-rice-i mport-bill-by-21pc-to-rs17b

[14] Food and Agriculture Organization of the United Nations (2019). http://www.fao.org/faostat/en/\#data/TP

[15] Rahman, A., Mamun, A., Afrooz, N., Howlader, S. and Khuda, A. (2017) Rice Processing Industry in Banglades. Emerging Credit Rating Limited. Baridhara, 17. http://emergingrating.com/wp-content/uploads/2017/09/Rice-Processing-Industryof-Bangladesh-Rice-Mill-2017.pdf

[16] Witcombe, J.R., Khadka, K., Puri, R.R., Khanal, N.P., Sapkota, A. and Joshi, K.D. (2016) Adoption of Rice Varieties-I. Age of Varieties and Patterns of Variability. Experimental Agriculture, 53, 512-527. https://doi.org/10.1017/S0014479716000545

[17] Witcombe, J.R., Khadka, K., Puri, R.R., Khanal, N.P., Sapkota, A. and Joshi, K.D. (2016) Adoption of Rice Varieties-II. Accelerating Uptake. Experimental Agriculture, 53, 627-643. https://doi.org/10.1017/S0014479716000624

[18] Joshi, K.D., Devkota, K.P., Harris, D., Khanal, N.P., Poudyal, B., Sapkota, A. and Witcombe, J.R. (2012) Participatory Research Approaches Rapidly Improve Household Food Security in Nepal and Identify Policy Changes Required for Insti- 
tutionalization. Field Crops Research, 131, 40-48.

https://doi.org/10.1016/j.fcr.2012.03.001

[19] Acharya, S. (2018) Cheap Imports Force Rice Mills to Close. Money.

https://kathmandupost.com/money/2018/02/06/cheap-imports-force-rice-mills-to-c $\underline{\text { lose }}$

[20] Portel, P. and Ghimire, M. (2017) Rising Rice Imports Hit Mills, Farmers in Eastern Tarai.

https://kathmandupost.com/money/2017/01/06/rising-rice-imports-hit-mills-farme rs-in-eastern-tarai

[21] The Himalayan Times (2015) Plagued by Problems Industry Insight. The Himalayan Times. https://thehimalayantimes.com/business/plagued-by-problems/

[22] Purusottam, N. (1996) Problems and Prospects of Rice Mill Modernization: A Case Study. Journal of Assam University, 1, 22-28. 